\title{
Physiological and phylogenetic characterization of a novel lithoautotrophic nitrite-oxidizing bacterium, 'Candidatus Nitrospira bockiana'
}

\author{
Correspondence \\ E. Spieck \\ spieck@mikrobiologie. \\ uni-hamburg.de
}

\author{
E. V. Lebedeva, ${ }^{1}$ M. Alawi, ${ }^{2}$ F. Maixner, ${ }^{3}$ P.-G. Jozsa, ${ }^{2}$ H. Daims ${ }^{3}$ \\ and E. Spieck ${ }^{2}$
${ }^{1}$ Winogradsky Institute of Microbiology, Russian Academy of Sciences, Prospect 60-let Oktyabrya 7/2, Moscow 117312, Russia
${ }^{2}$ Universität Hamburg, Biozentrum Klein Flottbek, Mikrobiologie, Ohnhorststr. 18, D-22609
Hamburg, Germany
${ }^{3}$ Department für Mikrobielle Ökologie, Universität Wien, Althanstr. 14, A-1090 Wien, Austria

\section{INTRODUCTION}

Lithoautotrophic nitrifying bacteria (NB) mediate the process of sequential oxidation of ammonia to nitrite and nitrate, known as nitrification. Physiologically, they are separated into ammonia- and nitrite-oxidizing bacteria ( $\mathrm{AOB}$ and $\mathrm{NOB}$, respectively). Initially, NB were grouped in the family Nitrobacteraceae. Differentiation of the genera was accomplished on the basis of physiological and morphological characteristics and the presence and arrangement of intracytoplasmic membranes (ICMs) (Watson et al., 1989). Molecular techniques such as $16 \mathrm{~S}$ rRNA gene sequencing have provided evidence for the phylogenetic heterogeneity of the NB (Teske et al., 1994; Ehrich et al., 1995; Purkhold et al., 2000).

Abbreviations: $\mathrm{AOB}$, ammonia-oxidizing bacteria; DGGE, denaturing gradient gel electrophoresis; EPS, extracellular polymeric substances; FISH, fluorescence in situ hybridization; ICMs, intracytoplasmic membranes; NB, nitrifying bacteria; NOB, nitrite-oxidizing bacteria.

The GenBank/EMBL/DDBJ accession numbers for the 16S rRNA gene sequences of 'Candidatus Nitrospira bockiana' and the enrichment clone are EU084879 and EU084880, respectively.

A supplementary figure of the DGGE profile showing the increasing purity of the enrichments is available with the online version of this paper.
Until recently, all of the recognized genera of bacterial ammonia oxidizers have been limited to two phylogenetically distinct groups affiliated to the classes Betaproteobacteria and Gammaproteobacteria within the phylum Proteobacteria. The first ammonia oxidizers of the domain Archaea, within the phylum Crenarchaeota, were isolated by Könneke et al. (2005). Existing genera of NOB have been classified taxonomically under two phyla in the domain Bacteria. The genera Nitrobacter, Nitrococcus and Nitrospina belong to the classes Alphaproteobacteria, Gammaproteobacteria and Deltaproteobacteria within the phylum Proteobacteria. The genus Nitrospira represents a monophyletic lineage within the deep-branching bacterial phylum Nitrospira (Ehrich et al., 1995; Spieck \& Bock, 2001), where they occur together with 'Candidatus Magnetobacterium bavaricum' and members of the genera Leptospirillum and Thermodesulfovibrio (Garrity \& Holt, 2001). So far, the genus Nitrospira is represented by two recognized species: Nitrospira marina (Watson et al., 1986) and Nitrospira moscoviensis (Ehrich et al., 1995), isolated from marine and freshwater habitats, as well as by 'Candidatus Nitrospira defluvii' (Spieck et al., 2006), highly enriched from activated sludge. Species of the genus Nitrospira are regarded to be obligate lithotrophs with the ability to perform mixotrophic growth (Watson et al., 1986). 
Investigations performed by cultivation-independent molecular methods (Burrell et al., 1998; Hovanec et al., 1998; Daims et al., 2001) and immunological techniques (Bartosch et al., 1999) clearly indicated that Nitrospira-like bacteria are widely distributed in different natural and engineered ecosystems. For example, it was shown that Nitrospira-types are the most common nitrite-oxidizers in wastewater treatment plants (Juretschko et al., 1998) and not Nitrobacter-types as was previously thought according to culture-based studies. Nitrospira-like bacteria were further detected in various soils (Bartosch et al., 2002; Noll et al., 2005) and freshwater sediments (Stein et al., 2001; Altmann et al., 2003). Recently, such organisms were also found to be present in thermophilic communities when studied by molecular and classical techniques (Kanokratana et al., 2004; Lebedeva et al., 2005).

In this study, we describe the physiological and phylogenetic characterization of a novel Nitrospira-like bacterium. The organism originated from internal corrosion deposits from a steel pipeline of the Moscow heating system, Russia. The first evidence for the existence of this novel Nitrospiralike bacterium was based on data from lipid profiles; in particular, the absence of the lipid component $16: 1$ cis 11 , a feature characteristic of the recognized species of the genus Nitrospira (Lipski et al., 2001; Spieck et al., 2006). The novel nitrite-oxidizing bacterium is provisionally named 'Candidatus Nitrospira bockiana' (following the naming convention of Murray \& Stackebrandt, 1995).

\section{METHODS}

Source of bacteria. The enrichment was carried out using material from internal corrosion deposits from the steel return pipeline of the Moscow heating system, Russia. Samples were collected during repair work in summer 1995. The temperature of water in the pipeline ranged from 40 to $70{ }^{\circ} \mathrm{C}$, depending on the heating season. A detailed description of the habitat from which the bacteria were obtained has been reported previously (Rozanova et al., 2003).

Cultivation. Primary enrichment of $\mathrm{NOB}$ was obtained at $42{ }^{\circ} \mathrm{C}$ in basal salt medium (Ehrich et al., 1995) supplemented with $1 \mathrm{mM}$ of nitrite as the only energy source. Later, if not stated otherwise, cultivation of enrichment cultures was carried out at $45{ }^{\circ} \mathrm{C}$ in $250 \mathrm{ml}$ flasks with $100 \mathrm{ml}$ mineral medium supplemented with $3-7 \mathrm{mM}$ of nitrite. The final isolate was cultivated at $42{ }^{\circ} \mathrm{C}$ with $0.3-3 \mathrm{mM}$ of nitrite. Growth was detected by measuring nitrite consumption; nitrite was regularly replaced to increase the cell density. Percoll density-gradient centrifugation and subsequent serial dilutions in a medium supplemented with $0.3 \mathrm{mM}$ of nitrite were performed as described by Ehrich et al. (1995).

The influence of organic matter was checked in a mineral medium with $3 \mathrm{mM}$ of nitrite supplemented with pyruvate $\left(55 \mathrm{mg} \mathrm{l}^{-1}\right)$ or yeast extract $\left(20 \mathrm{mg} \mathrm{l}^{-1}\right)$. The effect of vitamins, prepared according to Balch et al. (1979), was also tested. A complex medium was used to check whether the enriched organisms were capable of organotrophic growth. For this purpose, the basal mineral medium without nitrite was supplemented with pyruvate $\left(55 \mathrm{mg} \mathrm{l}^{-1}\right)$ as carbon source and yeast extract $\left(150 \mathrm{mg} \mathrm{l}^{-1}\right)$ and peptone $\left(150 \mathrm{mg} \mathrm{l}^{-1}\right)$ as nitrogen sources. The $\mathrm{pH}$ of the medium was adjusted to 7.6. Growth was monitored by light microscopic observations.
Isolation and investigation of Nocardioides sp. Samples of enrichment 5 were streaked onto plates of solid complex medium as mentioned above and incubated at $42{ }^{\circ} \mathrm{C}$. Single colonies were selected and spread onto plates again to obtain a pure culture. The ability of the isolate, identified as Nocardioides sp., to perform denitrification and nitrate reduction was tested in $20 \mathrm{ml}$ tubes filled with complex medium supplemented with $1 \mathrm{~g} \mathrm{l}^{-1}$ of sodium nitrate. The tubes also contained Durham tubes for collecting any gas formed by denitrification.

Analytical procedures. Nitrite and nitrate concentrations were determined quantitatively by HPLC in an automated system (MT2; Kontron Instruments). Separation was achieved by ion pair chromatography with a Hypersil ODS C18 column $(125 \times 4.6 \mathrm{~nm})$ (Meincke et al., 1992). Detection was performed by UV absorption at $225 \mathrm{~nm}$. Consumption of nitrite was detected qualitatively by the Griess-Ilosvay spot test (Schmidt \& Belser, 1982). Cell density was determined under a light microscope by direct cell counting.

Electron microscopy. Electron microscopy of whole cells and of ultrathin sections was carried out as described by Spieck et al. (2006) and samples were viewed in a transmission electron microscope (model 420, Philips or LEO-906E, Zeiss).

Denaturing gradient gel electrophoresis (DGGE) analyses. The partial $16 \mathrm{~S}$ rRNA genes in the enrichment cultures were amplified by PCR with the eubacterial primer set 346F/907R (Muyzer et al., 1998). A GC-clamp was added to the forward primer. DGGE was performed at a temperature of $59{ }^{\circ} \mathrm{C}$ with a gradient from $50-80 \%$ denaturants. Bands were extracted from the gel and reamplified and the partial $16 \mathrm{~S}$ rRNA gene sequences were compared with those available on publicly accessible databases by using the Basic Local Alignment Search Tool program (BLAST, NCBI).

Fluorescence in situ hybridization. Aliquots of the enrichments were prepared for fluorescence in situ hybridization (FISH) by fixation in paraformaldehyde according to Daims et al. (2005). Following fixation, the biomass was spotted onto microscope slides and FISH was performed according to Manz et al. (1992) and Daims et al. (2005). The applied oligonucleotide probes were S-G-Ntspa0662-a-A-18 (target group: genus Nitrospira) (Daims et al., 2001), S*-Ntspa-0712-a-A-21 (target group: phylum Nitrospira) (Daims et al., 2001), S-*-Ntspa-1151-a-A-20 (target group: sublineage II of the genus Nitrospira) (Maixner et al., 2006), S-G-Nbac-1035-a-A-18 (=NIT3; Wagner et al., 1996) (target group: genus Nitrobacter) and the EUB probe mix that detects almost all known Bacteria (Amann et al., 1990; Daims et al., 1999). The probes were 5'-labelled with either the FLUOS dye [5(6)-carboxyfluorescein- $N$-hydroxysuccinimide ester] or the sulfoindocyanine dye Cy3. The Nitrospira- and Nitrobacter-specific probes were used together with competitor oligonucleotides according to Daims et al. (2001) and Wagner et al. (1996). All probes and competitors were obtained from Thermo Scientific (Germany). Fluorescence signals were recorded with a confocal laser scanning microscope (LSM 510 Meta; Zeiss) by using an Ar ion laser to detect FLUOS (488 nm excitation wavelength) and a HeNe laser $(543 \mathrm{~nm})$ to detect Cy3, respectively.

Cloning and phylogenetic analysis of 16S rRNA genes. Bacterial 16S rRNA genes were amplified by PCR, cloned and sequenced as described by Maixner et al. (2006) with the only modification that instead of extracted genomic DNA, $1.5 \mu \mathrm{l}$ of Nitrospira enrichment was added directly to the PCR reaction mix for 16S rRNA gene amplification. Sequence alignments and phylogenetic analyses were carried out using ARB software (Ludwig et al., 2004) according to Daims et al. (2001). 


\section{RESULTS}

\section{Enrichment and isolation of 'Candidatus Nitrospira bockiana'}

The scheme of enrichment and isolation procedure for the novel Nitrospira isolate is presented in Table 1. The process was monitored by microscopic observations, FISH, DGGE and $16 \mathrm{~S}$ rRNA gene sequencing followed by phylogenetic analysis. The enrichment of $\mathrm{NOB}$ from material from corrosion deposits (as described above) resulted in the primary enrichment culture of spiral-shaped cells, cultivated at $42{ }^{\circ} \mathrm{C}$ (enrichment 1). In subculture, the consumed nitrite was regularly replaced to obtain a high cell density for the following working steps (enrichment 2). After application of the Percoll technique and subsequent dilution, enrichment 3 was obtained. Electron microscopic observations of ultrathin sections revealed that the most abundant cells resembled those of members of the genus Nitrospira (Fig. 1). Rarely encountered cells exhibited structural features of cells of members of the genus Nitrobacter, with a polar cap of intracytoplasmic membranes (data not shown). FISH with probes specific for the genus and phylum Nitrospira revealed that Nitrospira cells

Table 1. Scheme of enrichment and isolation of 'Candidatus Nitrospira bockiana'

\begin{tabular}{|c|c|c|c|c|}
\hline Treatment & Culture & $\begin{array}{l}\text { Incubation } \\
\text { temperature }\end{array}$ & $\begin{array}{l}\text { Methods used to } \\
\text { characterize culture }\end{array}$ & Composition of the culture \\
\hline $\begin{array}{l}\text { Mineral medium inoculated with } \\
\text { environmental sample }\end{array}$ & Enrichment 1 & $42{ }^{\circ} \mathrm{C}$ & Phase-contrast microscopy & Spiral shaped cells \\
\hline $\begin{array}{l}\text { Cultivation with regular replacement } \\
\text { of consumed nitrite }\end{array}$ & Enrichment 2 & $42{ }^{\circ} \mathrm{C}$ & Phase-contrast microscopy & Spiral shaped cells \\
\hline \multirow{4}{*}{$\begin{array}{l}\text { Percoll density-gradient centrifugation } \\
\text { with subsequent dilution series } \\
\text { resulted in harvesting the most } \\
\text { diluted }\left(10^{-7}\right) \text { nitrite-oxidizing } \\
\text { culture }\end{array}$} & Enrichment 3 & $42{ }^{\circ} \mathrm{C}$ & $\begin{array}{l}\text { Electron microscopy, } \\
\text { ultrathin sections }\end{array}$ & $\begin{array}{l}\text { Nitrospira-like cells }+ \text { Nitrobacter-like } \\
\text { cells }+ \text { different contaminants }\end{array}$ \\
\hline & & & $\begin{array}{l}\text { 16S rRNA partial gene } \\
\text { sequence }\end{array}$ & $\begin{array}{l}\text { 'Candidatus Nitrospira bockiana' + } \\
\text { Nitrospira moscoviensis-like }\end{array}$ \\
\hline & & & FISH & $\begin{array}{l}\text { 'Candidatus Nitrospira bockiana' + } \\
\text { N. moscoviensis-like }\end{array}$ \\
\hline & & & $\begin{array}{l}\text { Purity test in complex } \\
\text { medium }\end{array}$ & Several types of contaminants \\
\hline \multirow[t]{2}{*}{ Incubation at elevated temperature } & Enrichment 4 & $45^{\circ} \mathrm{C}$ & $\begin{array}{l}\text { Electron microscopy, } \\
\text { ultrathin sections }\end{array}$ & Nitrospira-like cells (no Nitrobacter) \\
\hline & & & FISH & $\begin{array}{l}\text { 'Candidatus Nitrospira bockiana' (no } \\
\text { N. moscoviensis-like cells). } \\
\text { Morphologically highly variable } \\
\text { nitrite-oxidizing culture }\end{array}$ \\
\hline \multirow{3}{*}{$\begin{array}{l}\text { Percoll density-gradient centrifugation } \\
\text { with subsequent dilution series } \\
\text { resulted in harvesting the most } \\
\text { diluted }\left(10^{-7}\right) \text { nitrite-oxidizing } \\
\text { culture }\end{array}$} & Enrichment 5 & $45^{\circ} \mathrm{C}$ & $\begin{array}{l}\text { Electron microscopy, } \\
\text { ultrathin sections }\end{array}$ & $\begin{array}{l}2 \text { types of cells: Nitrospira-like }+ \\
\text { Gram-positive contaminant }\end{array}$ \\
\hline & & & $\begin{array}{l}\text { DGGE with subsequent } 16 \mathrm{~S} \\
\text { rRNA partial gene sequence }\end{array}$ & $\begin{array}{l}2 \text { bands corresponding to 'Candidatus } \\
\text { Nitrospira bockiana' and } \\
\text { Nocardioides sp. (contaminant) }\end{array}$ \\
\hline & & & $\begin{array}{l}\text { Purity test in complex } \\
\text { medium }\end{array}$ & One type of contaminant \\
\hline \multirow{4}{*}{$\begin{array}{l}\text { Dilution series from a highly enriched } \\
\text { culture resulted in harvesting the } \\
\text { most diluted }\left(10^{-8}\right) \text { nitrite-oxidizing } \\
\text { culture. }\end{array}$} & Final isolate & $42{ }^{\circ} \mathrm{C}$ & $\begin{array}{l}\text { Electron microscopy, } \\
\text { negative staining }\end{array}$ & $\begin{array}{l}\text { Morphologically highly variable } \\
\text { Nitrospira cells }\end{array}$ \\
\hline & & & $\begin{array}{l}\text { DGGE with subsequent } 16 \mathrm{~S} \\
\text { rRNA partial gene sequence }\end{array}$ & $\begin{array}{l}\text { Only one band, corresponding to } \\
\text { 'Candidatus Nitrospira bockiana' }\end{array}$ \\
\hline & & & FISH & $\begin{array}{l}\text { 'Candidatus Nitrospira bockiana' - no } \\
\text { N. moscoviensis-like }\end{array}$ \\
\hline & & & $\begin{array}{l}\text { Purity test in complex } \\
\text { medium }\end{array}$ & No contaminant \\
\hline
\end{tabular}




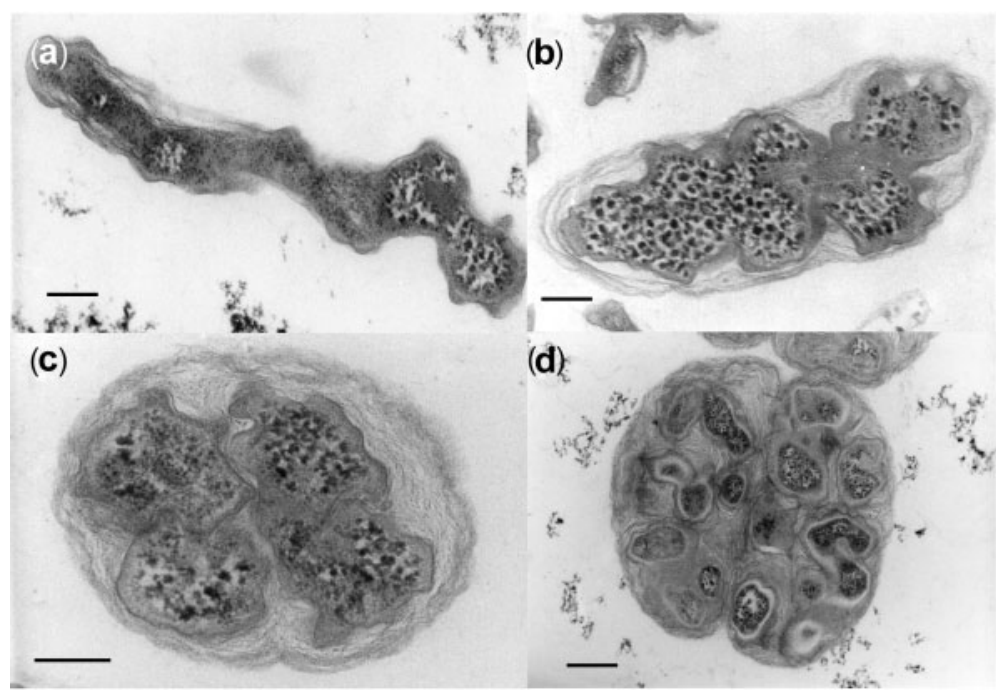

Fig. 1. Electron micrographs of ultrathin sections of cells of 'Candidatus Nitrospira bockiana' derived from the Moscow heating system (enrichment 3) showing the different stages in the formation of microcolonies. (a) Single planktonic cell. (b) Secretion of EPS accompanied by a decrease in cell length. (c) Small microcolony, where two cells are embedded in a common matrix of EPS. (d) Microcolony of Nitrospira containing multiple cells of variable shapes. Bars, $0.25 \mu \mathrm{m}(\mathrm{a}-\mathrm{c}) ; 0.5 \mu \mathrm{m}$ (d).

were abundant in the enrichment, but that it also contained at least two different Nitrospira populations (Table 1). Whereas most Nitrospira cells were detected only by the genus- and phylum-specific probes, a minor fraction also hybridized to probe S- $^{\star}$-Ntspa-1151-a-A-20, which is specific for the sublineage II of the genus Nitrospira (the Nitrospira moscoviensis lineage). At this point, phylogenetic analyses already indicated that the culture contained novel Nitrospira-like bacteria (see below). The temperature shift up to $45{ }^{\circ} \mathrm{C}$ provided a selective means for discrimination of the novel Nitrospira isolates from members of the genus Nitrobacter and members of the sublineage II Nitrospira (enrichment 4). A second Percoll gradient centrifugation, followed by a dilution series, resulted in enrichment 5 . Here, DGGE results indicated that only one type of contaminant was present. To increase the abundance of Nitrospira cells, the consumed nitrite was regularly replenished in order to obtain a highly enriched culture with visible turbidity. This culture was the starting material used for several dilution series. The enrichment process was monitored by DGGE analysis, where the intensity of the band belonging to the accompanying organism decreased (see Supplementary Fig. S1 in IJSEM Online). The so-called final isolate, containing 'Candidatus Nitrospira bockiana' was obtained at the dilution step of $10^{-8}$.

Since this Nitrospira-like bacterium was extremely pleomorphic, several tests were done to verify the absence of contaminants and other nitrite oxidizing species: (i) no heterotrophic growth in complex medium was observed, and (ii) DGGE analyses showed that after the purification procedures, the contaminant had disappeared and only one Nitrospira-like nitrite-oxidizing bacterium was present (see Supplementary Fig. S1). No members of the genus Nitrospira affiliated to sublineage II, members of the genus Nitrobacter or any other bacteria except 'Candidatus Nitrospira bockiana' were detected by FISH (Fig. 2). Thus, based on the results obtained by these monitoring strategies, the final enrichment was probably a pure culture of 'Candidatus Nitrospira bockiana'.

\section{Morphology of 'Candidatus Nitrospira bockiana'}

In enrichment 3 and in the culture of the final isolate, the morphology of the Nitrospira-like cells differed significantly. In enrichment 3, most Nitrospira-like cells were long, spiral rods. At this stage, a transition in cell shape suggesting a life cycle was observed. Initially, very long spiral rods occurred as planktonic cells (Fig. 1a). Then the cell length decreased, a process that was accompanied by intense formation of
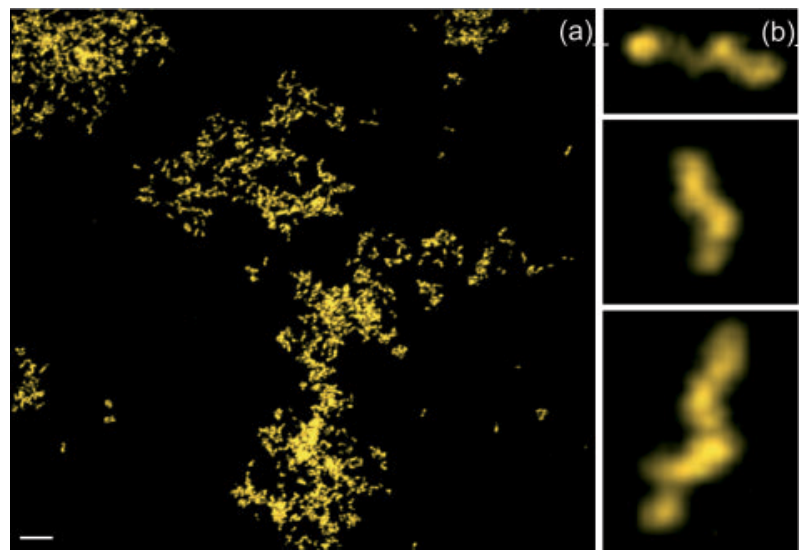

Fig. 2. (a) Detection of 'Candidatus Nitrospira bockiana' in the final isolate by FISH with probes S-G-Ntspa-0662-a-A-18 (red) and the EUB338 probe mix (green). Nitrospira cells appear yellow because of hybridization to all probes. Note the absence of any other bacteria. The contrast of this image was adjusted by image processing software. Bar, $5 \mu \mathrm{m}$. (b) Single cells of 'Candidatus Nitrospira bockiana' detected by FISH. The spiral morphology is clearly visible. The images of these cells were extracted from image (a) and then digitally magnified. 
extracellular polymeric substances (EPS) (Fig. 1b). Cells continued to divide inside small microcolonies (Fig. 1c) and finally, numerous short cells were organized in a dense layer of a biofilm matrix, where the spiral cell shape could hardly be detected anymore (Fig. 1d). In contrast, the cells of the final isolate occurred mainly as free-living planktonic cells and demonstrated extremely high morphological variability. Their cell shape ranged from loosely wound spirals (Fig. 3a) with a variable number of coils to slightly curved and even straight rods (Fig. 3b) as well as coccoid cells with a diameter of $0.9 \mu \mathrm{m}$ (Fig. $3 \mathrm{~d}$ ). The size of the spiral- and rod-shaped cells ranged from 0.3 to $0.6 \mu \mathrm{m}$ in width and from 1.0 to $2.5 \mu \mathrm{m}$ in length. The absence of motility was characteristic for all enrichment stages. Cells reproduced by binary or by unequal fission (Fig. 3c). As has already been shown for Nitrospira moscoviensis (Spieck et al., 1998), coccoid cells were found to contain membrane-bound particles (Fig. 3e),

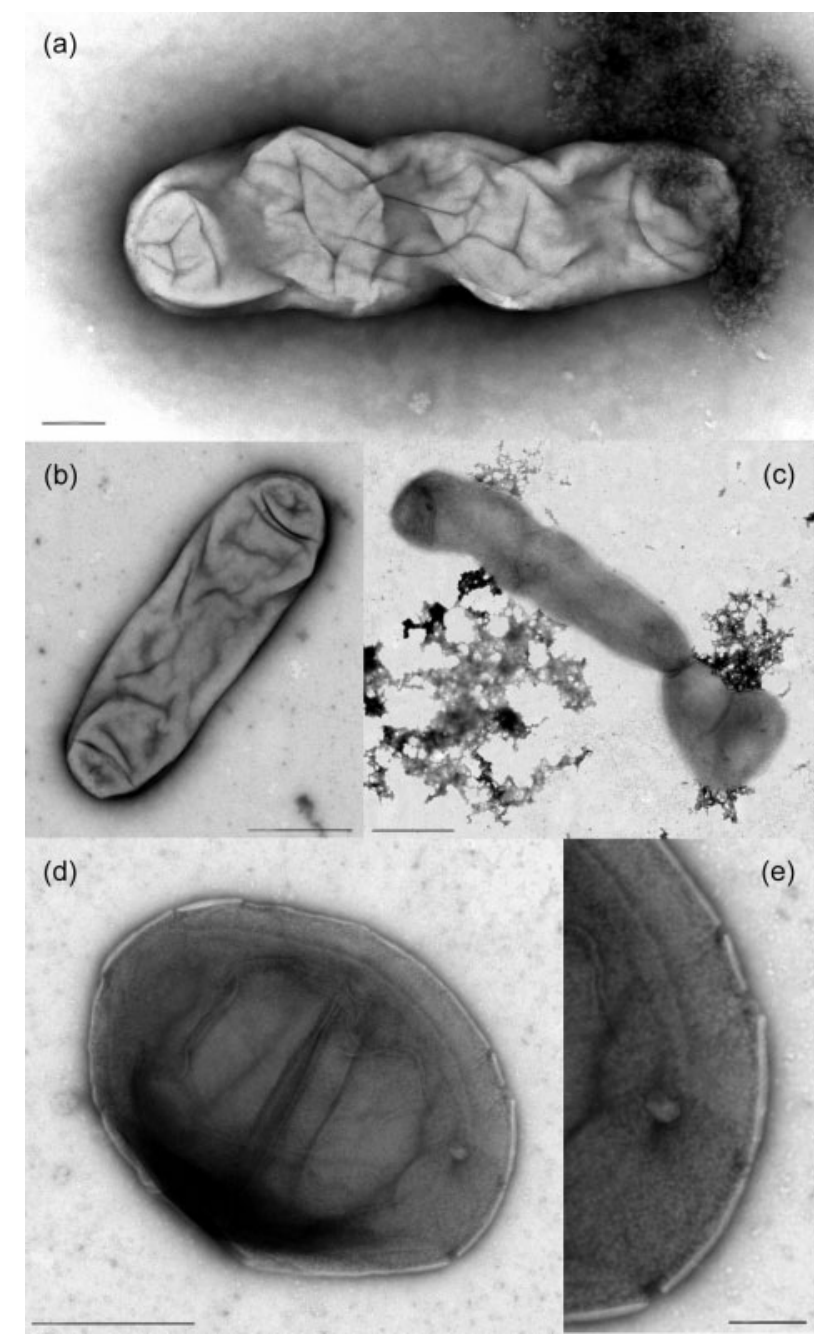

Fig. 3. Overall shape of 'Candidatus Nitrospira bockiana', stained with uranyl acetate. (a) Spiral rod; (b) long straight rod; (c) unequal fission; (d) coccoid cell; (e) section of (d) showing membrane-bound particles in detail. Bars, $0.2 \mu \mathrm{m}(\mathrm{a}) ; 0.5 \mu \mathrm{m}$ (b-d); $0.1 \mu \mathrm{m}(\mathrm{e})$. as revealed by negative staining. The particulate nitrite oxidizing system was localized on the periplasmic side of the cytoplasmic membrane, shining through the outer membrane in partially lysed cells.

During all enrichment stages, the ultrastructure of the cells was typical of that of members of the genus Nitrospira (Fig. la and b). In the observed ultrathin sections, the Nitrospira-like bacteria possessed an enlarged periplasmic space that is characteristic for this genus (Watson et al., 1986). No intracytoplasmic membranes or carboxysomes were found. As shown by electron microscopy, cells often contained glycogen and polyphosphate-like deposits as storage compounds.

\section{Physiological properties}

Physiological investigations started with enrichment 5, which was characterized as a co-culture of 'Candidatus Nitrospira bockiana' and Nocardioides sp. (see Supplementary Fig. S1). Enrichment 5 had the highest rate of nitrite consumption at around $45{ }^{\circ} \mathrm{C}$ (Fig. 4) at a $\mathrm{pH}$ of 7.6-8.0. The oxidation of nitrite correlated with an increase in the cell concentration (data not shown). The doubling time of the total cell number was between $8-9 \mathrm{~h}$ in a mineral medium with $6.8 \mathrm{mM}$ nitrite, which was oxidized within 4 days. Enrichment 5 was characterized by a wide tolerance of high nitrite concentrations, a characteristic previously noted for 'Candidatus Nitrospira defluvii' (Spieck et al., 2006). The substrate was oxidized at concentrations up to $26-30 \mathrm{mM}$ (Table 2).

In contrast to enrichment 5 , the temperature optimum of the final isolate dropped to $42{ }^{\circ} \mathrm{C}$ (Fig. 4). The highest tolerated nitrite concentration was also reduced to $18 \mathrm{mM}$ (Table 2). The rate of nitrite consumption of the final isolate was significantly lower when compared with enrichment 5, e.g, $5 \mathrm{mM}$ of nitrite was consumed within 10 days. Optimal growth occurred in a mineral salt medium with a relatively low nitrite concentration (0.3$1.5 \mathrm{mM}$ ). The addition of organic substances or vitamins did not enhance nitrite oxidation. Chemo-organotrophic growth was also not observed.

It was found that the temperature range of the nitriteoxidizing activity largely depended on the amount of nitrite. Starting with a low substrate concentration of $0.3 \mathrm{mM}$, enrichment 5 and the final isolate were able to oxidize nitrite between 17 and $48{ }^{\circ} \mathrm{C}$ and 17 to $44{ }^{\circ} \mathrm{C}$, respectively, while $1.5 \mathrm{mM}$ nitrite was oxidized within a temperature range of $28-48{ }^{\circ} \mathrm{C}$ and $28-44{ }^{\circ} \mathrm{C}$, respectively. Using a higher concentration of $6 \mathrm{mM}$ nitrite, growth of enrichment 5 was restricted to an even narrower temperature range of 37 to $48{ }^{\circ} \mathrm{C}$.

\section{Characterization of the contaminant}

Based on phylogeny using partial 16S rRNA gene sequences, the accompanying heterotrophic organism was 


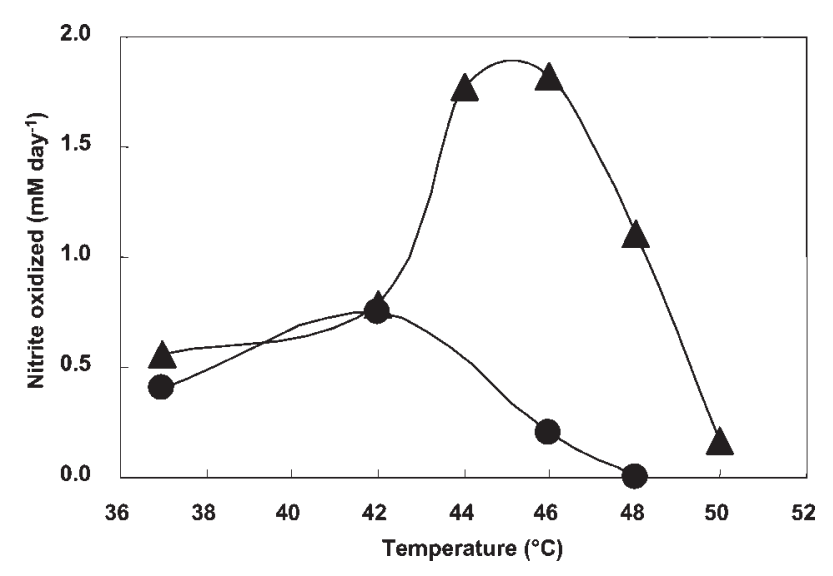

Fig. 4. Temperature optima for nitrite consumption by enrichment 5 and 'Candidatus Nitrospira bockiana'. $\boldsymbol{\Delta}$, enrichment 5 ; inoculum was taken from a pre-culture grown at $45^{\circ} \mathrm{C}$. Nitrite consumption was measured between day 3 and 4 with $5 \mathrm{mM}$ as substrate concentration. - final isolate; inoculum was taken from a preculture grown at $42{ }^{\circ} \mathrm{C}$. Nitrite consumption was measured between day 4 and 5 with $1.5 \mathrm{mM}$ as substrate concentration.

identified as Nocardioides sp. in the family Nocardiodaceae, a member of the phylum Actinomycetales (Yoon et al., 2005). The Nocardioides sp. was Gram-positive, aerobic, rod-shaped $(0.4-0.7 \times 0.5-1.3 \mu \mathrm{m})$ or coccoid $(0.7 \mu \mathrm{m}$ in diameter) cells. No motile forms were observed. The organism was able to perform reduction of nitrate, but not complete denitrification.

\section{Phylogenetic analysis}

Phylogenetic analyses of $16 \mathrm{~S}$ rRNA genes revealed that the final isolate, 'Candidatus Nitrospira bockiana', was a novel Nitrospira-like bacterium which did not group with any previously known sublineages (Daims et al., 2001) of the genus Nitrospira (Fig. 5). Three partial 16S rRNA gene sequences of 'Candidatus Nitrospira bockiana' (1158 nucleotides) from the final isolate were analysed and found to be highly similar to each other $(99.8-99.9 \%$ gene sequence similarity). The few base differences were probably due to PCR or sequencing errors. From earlier enrichments (but not from the final isolate), 16S rRNA gene sequences were retrieved for a second Nitrospira-like bacterium that fell into sublineage II of the genus Nitrospira, a lineage that also contains the cultured species Nitrospira moscoviensis (Fig. 5). This finding is consistent with the results of FISH with different Nitrospira-specific probes shown above.

\section{DISCUSSION}

In this paper, we describe the isolation and physiological characterization of a novel lithoautotrophic nitrite-oxidizing bacterium. This is the second investigation of a novel species of a nitrite-oxidizing bacterium belonging to the genus Nitrospira derived from the Moscow heating system. It is interesting that in the first enrichments obtained in this study at least two different strains of Nitrospira were found. The coexistence of various Nitrospira strains in the same environment has been earlier reported in studies on activated sludge and biofilms (Maixner et al., 2006) and in grassland soils (Freitag et al., 2005). Similarly, the coexistence of different strains of Nitrospira in a hot spring of the

Table 2. Comparison of key characteristics of the different species belonging to the genus Nitrospira

Taxa: 1, 'Candidatus Nitrospira bockiana'; 2, 'Candidatus Nitrospira defluvii'; 3, Nitrospira moscoviensis; 4, Nitrospira marina. Data were taken from Spieck et al. (2006), Spieck \& Bock (2001) and Lipski et al. (2001).

\begin{tabular}{|c|c|c|c|c|}
\hline Characteristic & 1 & 2 & 3 & 4 \\
\hline Cell morphology & $\begin{array}{l}\text { Spirals, curved and straight } \\
\text { rods or coccoid cells }\end{array}$ & $\begin{array}{l}\text { Short, slightly curved cells } \\
\text { or spiral-shaped rods }\end{array}$ & $\begin{array}{l}\text { Irregularly shaped cells } \\
\text { or spiral-shaped rods }\end{array}$ & $\begin{array}{l}\text { 'Comma-shaped' cells } \\
\text { or spiral-shaped rods }\end{array}$ \\
\hline Turns & $1-4$ & $1-4$ & $1-3$ & $1-12$ \\
\hline Tendency to aggregate & Present & Strong & Present & Weak \\
\hline $\begin{array}{l}\text { Optimum growth } \\
\text { temperature }\left({ }^{\circ} \mathrm{C}\right)\end{array}$ & $44-46^{\star}, 42 \dagger$ & $28-32$ & 39 & 28 \\
\hline Medium & Non-marine & Non-marine & Non-marine & Marine \\
\hline $\begin{array}{l}\text { Phylogenetic affiliation in } \\
\text { genus Nitrospira }\end{array}$ & Novel sublineage & Sublineage I & Sublineage II & Sublineage IV \\
\hline Dominant lipids & $\begin{array}{l}16: 1 \text { cis } 7,16: 0 \\
16: 011 \text { methyl }\end{array}$ & $16: 1$ cis $11,16: 0$ & $\begin{array}{l}16: 1 \text { cis } 11,16: 0 \\
16: 011 \text { methyl }\end{array}$ & $16: 1$ cis $7,16: 1$ cis $11,16: 0$ \\
\hline $\begin{array}{l}\text { Tolerance against nitrite } \\
(\mathrm{mM})\end{array}$ & $26-30^{\star}, 18 \dagger$ & $20-25$ & 15 & 6 \\
\hline
\end{tabular}

${ }^{\star}$ Enrichment 5 .

$\dagger$ Final isolate. 


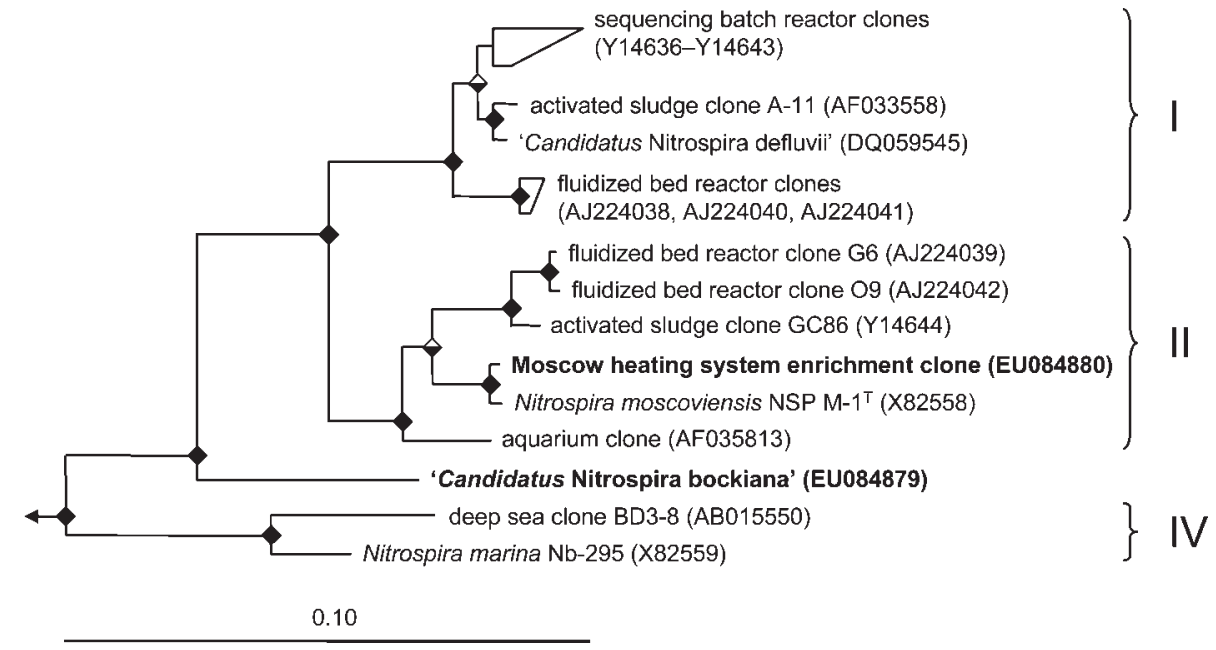

Fig. 5. Phylogenetic affiliation of 'Candidatus Nitrospira bockiana'. The phylogenetic tree is based on $16 \mathrm{~S}$ rRNA genes of selected Nitrospira-like bacteria. Sequences of 'Candidatus Nitrospira bockiana' and of another Nitrospira-like bacterium, which was found only in the early enrichment, are highlighted in bold. The tree calculation was performed using the maximum-likelihood algorithm of the ARB software package (Ludwig et al., 2004). A $50 \%$ conservation filter for the genus Nitrospira was applied to 1158 informative positions of the 16S rRNA genes. Partially filled diamonds represent quartet puzzling reliability values $\geqslant 70 \%$. Filled diamonds symbolize additional high parsimony bootstrap support ( $\geqslant 90 \%)$ based on 100 iterations. Previously defined (Daims et al., 2001) sublineages of the genus Nitrospira (numbers I, II and IV) are shown with brackets. Bar, $10 \%$ estimate sequence divergence.

Baikal rift zone was suggested by partial $16 \mathrm{~S}$ rRNA gene sequence analysis of DNA fragments (Lebedeva et al., 2005).

Adaptation to higher temperatures is a physiological feature which distinguishes the novel Nitrospira-like isolate from Nitrospira moscoviensis amd Nitrospira marina as well as from 'Candidatus Nitrospira defluvii' (Table 2). During the enrichment and isolation procedures, this characteristic was used successfully in order to discriminate 'Candidatus Nitrospira bockiana' from the genus Nitrobacter and members of the sublineage II of the genus Nitrospira.

The painstaking isolation of 'Candidatus Nitrospira bockiana' described in this study is the result of 12 years of work. The main reasons for the difficulties in purification were the abilities of the organism to form extracellular polymeric substances and to form microcolonies that also enclosed contaminants. Once purification procedures for free-living planktonic cells were employed, an enrichment that could be further purified by dilution techniques was finally obtained. The results of classical (no growth observed in complex medium) and molecular (DGGE, FISH) tests suggest that the finally-obtained culture was free from contaminants and other NOB. However, the presence of low numbers of other organisms cannot be excluded as the detection limit of FISH is $10^{3}-10^{4}$ cells ml $^{-1}$ (Amann, 1995) and populations below $1 \%$ of the total bacterial community may not be detectable by DGGE (Muyzer et al., 1993).

It is interesting to note that Nitrospira strains growing in co-culture with a Nocardioides sp. (enrichment 5) could resist higher nitrite concentrations and were shown to possess a higher temperature tolerance (Table 2) when compared with the final isolate. Keeping in mind the loss of organic matter by autotrophically growing NOB (Rittmann et al., 1994; Kindaichi et al., 2004), Nitrospira strains might supply the Nocardioides sp. with organic carbon for cell growth. The reason for the stimulation of Nitrospira strains by the contaminant is still unknown and remains to be clarified in further studies.

The data from lipid profiles were in accordance with the results of the 16S rRNA sequence analyses and suggest that 'Candidatus Nitrospira bockiana' is related, but not identical, to the recognized species of the genus Nitrospira. As shown by Lipski et al. (2001), the culture contains the dominant lipid components $16: 0 ; 16: 011$ methyl and $16: 1$ cis 7 and lacks $16: 1$ cis 11 , a lipid profile that is typical of the other recognized Nitrospira species. Based on physiological differences, chemotaxonomic data and on $16 \mathrm{~S}$ rRNA gene sequence analysis, we provisionally designate this organism as 'Candidatus Nitrospira bockiana' (as per the naming convention proposed by Murray \& Stackebrandt, 1995)

\section{Description of 'Candidatus Nitrospira bockiana'}

Nitrospira bockiana (bock.i.a.na. N.L. fem. adj. bockiana named after Professor Eberhard Bock, a microbiologist who devoted his research to the investigation of NB).

The organism is phylogenetically related to the genus Nitrospira. Gram-negative. Multiplication takes place by binary as well as by inequal fission. A chemolithoautotroph that oxidizes nitrite to nitrate and is able to use carbon 
dioxide as a sole carbon source. The highest rate of nitrite consumption occurs at $42{ }^{\circ} \mathrm{C}$, with a temperature range between 28 and $44{ }^{\circ} \mathrm{C}$. Pleomorphic cells range from loosely wound spirals with a variable number of coils to slightly curved and even straight rods, as well as coccoid cells $(0.9 \mu \mathrm{m}$ diameter $)$. The width of the spiral and rodshaped cells ranges from 0.3 to $0.6 \mu \mathrm{m}$ and the length ranges from 1.0 to $2.5 \mu \mathrm{m}$. Major fatty acids are $16: 0 ; 16: 0$ 11 methyl and $16: 1$ cis7. Neither pyruvate nor yeast extract stimulates nitrite oxidation. Organotrophic growth is not observed.

\section{ACKNOWLEDGEMENTS}

The authors would like to thank Irmhild Wachholz and Elke Wölken for excellent technical assistance in electron microscopy and Christian Baranyi for DNA sequencing. Sabine Bartosch is acknowledged for providing electron micrographs. This work was partly supported by the Deutsche Forschungsgemeinschaft (667 to E. S., 436 RUS 17/112/ 06 to E.V.L.) and by the Vienna Science and Technology Fund (WWTF project LS 216 to H.D.).

\section{REFERENCES}

Altmann, D., Stief, P., Amann, R., De Beer, D. \& Schramm, A. (2003). In situ distribution and activity of nitrifying bacteria in freshwater sediment. Environ Microbiol 5, 798-803.

Amann, R. I. (1995). In situ identification of micro-organisms by whole cell hybridization with rRNA-targeted nucleic acid probes. In Molecular Microbial Ecology Manual, pp. 1-15. Edited by A. D. C. Akkeman, J. D. van Elsas \& F. J. de Bruigin. Dortrecht: Kluwer Academic Publishers.

Amann, R. I., Binder, B. J., Olson, R. J., Chisholm, S. W., Devereux, R. \& Stahl, D. A. (1990). Combination of $16 \mathrm{~S}$ rRNA-targeted oligonucleotide probes with flow cytometry for analyzing mixed microbial populations. Appl Environ Microbiol 56, 1919-1925.

Balch, W. E., Fox, G. E., Magrum, L. J., Woese, C. R. \& Wolfe, R. S. (1979). Methanogens: reevaluation of a unique biological group. Microbiol Rev 43, 260-296.

Bartosch, S., Wolgast, I., Spieck, E. \& Bock, E. (1999). Identification of nitrite-oxidizing bacteria with monoclonal antibodies recognizing the nitrite oxidoreductase. Appl Environ Microbiol 65, 4126-4133.

Bartosch, S., Hartwig, C., Spieck, E. \& Bock, E. (2002). Immunological detection of Nitrospira-like bacteria in various soils. Microb Ecol 43, 26-33.

Burrell, P. C., Keller, J. \& Blackall, L. L. (1998). Microbiology of a nitrite-oxidizing bioreactor. Appl Environ Microbiol 64, 1878-1883.

Daims, H., Brühl, A., Amann, R., Schleifer, K.-H. \& Wagner, M. (1999). The domain-specific probe EUB338 is insufficient for the detection of all Bacteria: development and evaluation of a more comprehensive probe set. Syst Appl Microbiol 22, 434-444.

Daims, H., Nielsen, J. L., Nielsen, P. H., Schleifer, K. H. \& Wagner, M. (2001). In situ characterization of Nitrospira-like nitrite-oxidizing bacteria active in wastewater treatment plants. Appl Environ Microbiol 67, 5273-5284.

Daims, H., Stoecker, K. \& Wagner, M. (2005). Fluorescence in situ hybridization for the detection of prokaryotes. In Advanced Methods in Molecular Microbial Ecology, pp. 213-239. Edited by A. M. Osborn \& C. J. Smith. Abingdon, UK: Bios-Garland.
Ehrich, S., Behrens, D., Lebedeva, E., Ludwig, W. \& Bock, E. (1995). A new obligately chemolithoautotrophic, nitrite-oxidizing bacterium, Nitrospira moscoviensis sp. nov. and its phylogenetic relationship. Arch Microbiol 164, 16-23.

Freitag, T. E., Chang, L., Clegg, C. D. \& Prosser, J. I. (2005). Influence of inorganic nitrogen management regime on the diversity of nitriteoxidizing bacteria in agricultural grassland soils. Appl Environ Microbiol 71, 8323-8334.

Garrity, G. M. \& Holt, J. G. (2001). Phylum BVIII. Nitrospirae phy. nov. In Bergey's Manual of Systematic Bacteriology: The Archaea and the Deeply Branching and Phototrophic Bacteria, pp. 451-464. Edited by D. R. Boone, R. W. Castenholz \& G. M. Garrity. New York, NY: Springer-Verlag.

Hovanec, T. A., Taylor, L. T., Blakis, A. \& DeLong, E. F. (1998). Nitrospira-like bacteria associated with nitrite oxidation in freshwater aquaria. Appl Environ Microbiol 64, 258-264.

Juretschko, S., Timmermann, G., Schmid, M., Schleifer, K.-H., Pommerening-Röser, A., Koops, H.-P. \& Wagner, M. (1998). Combined molecular and conventional analyses of nitrifying bacterium diversity in activated sludge: Nitrosococcus mobilis and Nitrospira-like bacteria as dominant populations. Appl Environ Microbiol 64, 3042-3051.

Kanokratana, P., Chanapan, S., Pootanakit, K. \& Eurwilaichitr, L. (2004). Diversity and abundance of bacteria and archaea in the Bor Khlueng hot spring in Thailand. J Basic Microbiol 44, 430-444.

Kindaichi, T., Ito, T. \& Okabe, S. (2004). Ecophysiological interaction between nitrifying bacteria and heterotrophic bacteria in autotrophic nitrifying biofilms as determined by microautoradiography-fluorescence in situ hybridization. Appl Environ Microbiol 70, 1641-1650.

Könneke, M., Bernhard, A. E., de la Torre, J. R., Wolker, C. B., Waterbury, J. B. \& Stahl, D. A. (2005). Isolation of an autotrophic ammonia-oxidizing marine archaeon. Nature 437, 543-546.

Lebedeva, E. V., Alawi, M., Fiencke, C., Namsaraev, B., Bock, E. \& Spieck, E. (2005). Moderately thermophilic nitrifying bacteria from a hot spring of the Baikal rift zone. FEMS Microbiol Ecol 54, 297-306.

Lipski, A., Spieck, E., Makolla, A. \& Altendorf, K. (2001). Fatty acid profiles of nitrite-oxidizing bacteria reflect their phylogenetic heterogeneity. Syst Appl Microbiol 24, 377-384.

Ludwig, W., Strunk, O., Westram, R., Richter, L., Meier, H., Yadhu, K., Buchner, A., Lai, T., Steppi, S. \& other authors (2004). ARB: a software environment for sequence data. Nucleic Acids Res 32, 1363-1371.

Maixner, F., Noguera, D. R., Anneser, B., Stoecker, K., Wegl, G., Wagner, M. \& Daims, H. (2006). Nitrite concentration influences the population structure of Nitrospira-like bacteria. Environ Microbiol 8, 1487-1495.

Manz, W., Amann, R. I., Ludwig, W., Wagner, M. \& Schleifer, K. H. (1992). Phylogenetic oligodeoxynucleotide probes for the major subclasses of proteobacteria: problems and solutions. Syst Appl Microbiol 15, 593-600.

Meincke, M., Bock, E., Kastrau, D. \& Kroneck, P. M. H. (1992). Nitrite oxidoreductase from Nitrobacter hamburgensis: redox centers and their catalytic role. Arch Microbiol 158, 127-131.

Murray, R. G. \& Stackebrandt, E. (1995). Taxonomic note: implementation of the provisional status Candidatus for incompletely described procaryotes. Int J Syst Bacteriol 45, 186-187.

Muyzer, G., de Waal, E. C. \& Uitterlinden, A. G. (1993). Profiling of complex microbial populations by denaturing gradient gel electrophoresis analysis of polymerase chain reaction-amplified genes coding for $16 \mathrm{~S}$ rRNA. Appl Environ Microbiol 59, 695-700.

Muyzer, G., Brinkhoff, T., Nübel, U., Santegoeds, C., Schäfer, H. \& Wawer, C. (1998). Denaturing gradient gel electrophoresis (DGGE) in microbial ecology. In Molecular Microbial Ecology Manual, vol. 3.4.4, 
pp. 1-27. Edited by A. D. L. Akkermans, J. D. van Elsas, and F. J. de Bruijn. Drodrecht: Kluwer.

Noll, M., Matthies, D., Frenzel, P., Derakshani, M. \& Liesack, W. (2005). Succession of bacterial community structure and diversity in a paddy soil oxygen gradient. Environ Microbiol 7, 382-395.

Purkhold, U., Pommerening-Röser, A., Juretschko, S., Schmid, M. C., Koops, H.-P. \& Wagner, M. (2000). Phylogeny of all recognized species of ammonia oxidizers based on comparative 16S rRNA and amoA sequence analysis: implications for molecular diversity surveys. Appl Environ Microbiol 66, 5368-5382.

Rittmann, B. E., Regan, J. M. \& Stahl, D. A. (1994). Nitrification as a source of soluble organic substrate in biological treatment. Water Sci Technol 30, 1-8.

Rozanova, E. P., Dubinina, G. A., Lebedeva, E. V., Suntsova, L. A., Lipovskich, V. M. \& Tsvetkov, N. N. (2003). Microorganisms in heat supply systems and internal corrosion of steel pipelines. Microbiology (English translation of Microbiologiia). 72, 212-220.

Schmidt, E. L. \& Belser, L. W. (1982). Nitrifying bacteria. In Methods of Soil Analysis, Part 2. Chemical and Microbiological Properties (American Society of Agronomy Monograph no. 9), pp. 1027-1042. Edited by A. L. Page, R. H. Miller \& D. R. Keeney. Madison: American Society of Agronomy.

Spieck, E. \& Bock, E. (2001). Genus Nitrospira. In Bergey's Manual of Systematic Bacteriology: The Archaea and the Deeply Branching and Phototrophic Bacteria, pp. 451-453. Edited by D. R. Boone, R. W. Castenholz \& G. M. Garrity. New York, NY: Springer-Verlag.
Spieck, E., Ehrich, S., Aamand, J. \& Bock, E. (1998). Isolation and immunocytochemical location of the nitrite-oxidizing system in Nitrospira moscoviensis. Arch Microbiol 169, 225-230.

Spieck, E., Hartwig, C., McCormack, I., Maixner, F., Wagner, M., Lipski, A. \& Daims, H. (2006). Selective enrichment and molecular characterization of a previously uncultured Nitrospira-like bacterium from activated sludge. Environ Microbiol 8, 405-415.

Stein, L. Y., La Duc, M. T., Grundl, T. J. \& Nealson, K. H. (2001). Bacterial and archaeal populations associated with freshwater ferromanganous micronodules and sediments. Environ Microbiol 3, 10-18.

Teske, A., Alm, E., Regan, J. M., Toze, S., Rittmann, B. E. \& Stahl, D. A. (1994). Evolutionary relationships among ammonia- and nitriteoxidizing bacteria. J Bacteriol 176, 6623-6630.

Wagner, M., Rath, G., Koops, H.-P., Flood, J. \& Amann, R. (1996). In situ analysis of nitrifying bacteria in sewage treatment plants. Water Sci Technol 34, 237-244.

Watson, S. W., Bock, E., Valois, F. W., Waterbury, J. B. \& Schlosser, U. (1986). Nitrospira marina gen. nov., sp. nov.: a chemolithotrophic nitrite-oxidizing bacterium. Arch Microbiol 144, 1-7.

Watson, S. W., Bock, E., Harms, H., Koops, H.-P. \& Hooper, A. B. (1989). Nitrifying bacteria. In Bergey's Manual of Systematic Bacteriology, vol. 3, pp. 1808-1834. Edited by J. T. Stanley, M. P. Bryant, N. Pfennig \& J. G. Holt. Baltimore, MD: Williams \& Wilkins Co.

Yoon, J. H., Kim, I. G., Lee, M. H. \& Oh, T. K. (2005). Nocardioides kribbensis sp. nov., isolated from an alkaline soil. Int J Syst Evol Microbiol 55, 1611-1614. 